\title{
Erratum to: Art, Ethics and the Promotion of Human Dignity
}

\author{
Nicola M. Pless ${ }^{1} \cdot$ Thomas Maak $^{1} \cdot$ Howard Harris $^{1}$
}

Published online: 29 May 2017

(C) Springer Science+Business Media Dordrecht 2017

\section{Erratum to: J Bus Ethics \\ DOI 10.1007/s10551-017-3467-9}

The paper authored by Adler and Delbecq, "Twenty-first century leadership: a return to beauty", that is referred to in this article has not been published in the Journal of Business Ethics as it has been withdrawn by the author.

The online version of the original article can be found under doi:10.1007/s10551-017-3467-9.

Thomas Maak

thomas.maak@unisa.edu.au

1 School of Management, University of South Australia, 47-55

North Terrace, Adelaide, SA 5000, Australia 